\title{
PROSES KOTA DENPASAR MENUJU SMART CITY
}

\begin{tabular}{|c|}
\hline I Made Satya Graha \\
Magister Perencanaan Wilayah dan Kota, Universitas Gadjah Mada, \\
Yogyakarta, Indonesia \\
satyabersatu@gmail.com
\end{tabular}

Diterima: Oktober 2019; Disetujui: April 2020

\begin{abstract}
Cities in Indonesia are currently developing smart cities. Denpasar City can be the best practice of developing a smart city in Indonesia. This study aims to determine the processes and factors that influence the process of Denpasar City in achieving the first rank of the smart city. This research uses a qualitative inductive approach with a case study strategy. The results of this study reveal that there are three stages by the City of Denpasar in achieving the first rank of smart city, namely stage I of ICT development, phase II of community development and the presence of PRO Denpasar, stage III of the innovation-oriented smart city. This study also found that Denpasar City developed two new dimensions, namely smart philosophy and smart creativity. The two new dimensions are not found in the theory or development of smart cities in other cities.
\end{abstract}

Keywords: Process, Factors, Smart City, City of Denpasar

\begin{abstract}
Abstraksi. Kota-kota di Indonesia saat ini sedang mengembangkan smart city. Kota Denpasar dapat menjadi best pratice pengembangan smart city di Indonesia. Penelitian ini bertujuan untuk mengetahui proses dan faktor-faktor yang mempengaruhi proses Kota Denpasar dalam meraih peringkat pertama smart city. Penelitian ini menggunakan pendekatan induktif kualitatif dengan strategi studi kasus. Hasil penelitian ini mengungkapkan bahwa terdapat tiga tahapan yang dilakukan Kota Denpasar dalam meraih peringkat pertama smart city, yakni tahap I pengembangan TIK, tahap II pembangunan masyarakat dan hadirnya PRO Denpasar, tahap III inovasi berorientasi smart city. Penelitian ini juga menemukan bahwa Kota Denpasar mengembangkan dua dimensi baru, yakni smart philosophy, dan smart creativity. Dua dimensi baru tersebut tidak terdapat pada teori atau pengembangan smart city di kota lainnya.
\end{abstract}

Kata kunci: Proses, Faktor-faktor, Smart City, Kota Denpasar

\section{PENDAHULUAN}

Kota Denpasar merupakan juara pertama kota cerdas pada ketegori kota besar, berdasarkan penilaian yang dilakukan oleh Kompas dengan tajuk Indeks Kota Cerdas Indonesia (IKCI) 2018. Setiap kota tentunya ingin mendapatkan juara pertama kota cerdas. Fenomena di lapangan menunjukan sudah banyaknya kota-kota di Indonesia yang mulai menerapkan kota cerdas (smart city), namun kenyataannya banyak yang belum dapat meraih peringkat pertama kota cerdas. Kota Denpasar sebagai kota yang meraih peringkat pertama kota cerdas IKCI 2018 memiliki keunikan tersendiri, sehingga menarik untuk dilakukan penelitian mengenai proses dan faktor-faktor yang mempengaruhi Kota Denpasar menuju smart city.

Penelitian yang dilakukan dengan mengambil lokus di Kota Denpasar ini dapat menjadi best pratice atau bahan kanjian bagi kota-kota lainnya di Indonesia dalam mengembangkan kota cerdas. Pemerintah kota lainnya di Indonesia dapat melakukan kombinasi dan kreasi dalam mengembangkan kota cerdas, mengingat istilah kota cerdas masih baru di Indonesia, 
dan pemerintah kota masih awam dalam penerapannya.

Penelitian ini menggunakan metode studi kasus dikarenakan keunikan Kota Denpasar yang meraih peringkat pertama IKCI 2018. Dikarenakan penilaian yang dilakukan oleh IKCI 2018 menggunakan indikator dari Smart City Wheel, sehingga untuk mengetahui proses yang dilakukan Kota Denpasar dalam mencapai peringkat pertama kota cerdas IKCI 2018 menggunakan indikator dari Smart City Wheel yang dicetuskan oleh Boyd Cohen.

Penelitian yang pernah dilakukan selama ini belum ada yang membahas mengenai proses Kota Denpasar menuju smart city. Namun, penelitian serupa yang pernah dilakukan sebelumnya yakni di Kota Surabaya yang merupakan kategori kota metropolit (Widyaningsih, 2013), kemudian mengenai infrastruktur cerdas (Widowati, 2017).

Penelitian ini akan memberikan wawasan mengenai proses yang dilakukan oleh Kota Denpasar dalam mencapai peringkat pertama smart city, sehingga dapat bermanfaat dalam pengembangan keilmuan dan penerapan smart city di Indonesia. Mengingat smart city merupakan kajian keilmuaan yang masih baru, namun banyak yang sudah tidak sabar menantinya.

\section{METODE PENELITIAN}

Pendekatan yang digunakan dalam penelitian ini adalah induktif kualitatif dengan strategi studi kasus. Strategi tersebut digunakan karena penelitian ini berfokus pada proses dan faktor-faktor yang mempengaruhi proses yang dilakukan Kota Denpasar dalam mencapai peringkat pertama smart city IKCI 2018. Cresswell (2017) menyampaikan bahwa penelitian studi kasus menyelidiki secara cermat suatu program, peristiwa, aktivitas, proses, atau sekelompok individu. proses yang dilakukan pemerintah Kota Denpasar dalam mencapai peringkat pertama smart city diselidiki dengan pertanyaan bagaimana (how) dan faktor-faktor yang mempengaruhi proses tersebut diselidiki dengan pertanyaan mengapa (why).

Tabel 1.

Proposisi Penelitian

\begin{tabular}{|c|c|c|c|c|}
\hline No & Dimensi & \multicolumn{3}{|c|}{ Sub-dimensi } \\
\hline 1 & Lingkungan & $\begin{array}{l}\text { Bangunan } \\
\text { cerdas }\end{array}$ & $\begin{array}{l}\text { Manajemen } \\
\text { suberdaya }\end{array}$ & $\begin{array}{l}\text { Perencanaan } \\
\text { berkelanjutan }\end{array}$ \\
\hline 2 & Mobilitas & $\begin{array}{l}\text { Transportasi } \\
\text { yang efisien }\end{array}$ & $\begin{array}{l}\text { Akses multi } \\
\text { moda }\end{array}$ & $\begin{array}{l}\text { Infrastruktur } \\
\text { teknologi }\end{array}$ \\
\hline 3 & Pemerintah & $\begin{array}{l}\text { Layanan } \\
\text { daring }\end{array}$ & $\begin{array}{l}\text { Infrastruktur } \\
\text { pendukung } \\
\text { sistem }\end{array}$ & $\begin{array}{l}\text { Keterbukaan data } \\
\text { pemerintah }\end{array}$ \\
\hline 4 & Ekonomi & $\begin{array}{l}\text { Kewirausahaan } \\
\text { dan inovasi }\end{array}$ & Produktivitas & $\begin{array}{l}\text { Jaringan bisnis } \\
\text { dalam dan luar } \\
\text { negeri }\end{array}$ \\
\hline 5 & Masyarakat & $\begin{array}{l}\text { Inklusivitas } \\
\text { sosial }\end{array}$ & Pendidikan & Kreativitas \\
\hline 6 & $\begin{array}{l}\text { Kualitas } \\
\text { Hidup }\end{array}$ & $\begin{array}{l}\text { Budaya dan } \\
\text { kesejahteraan }\end{array}$ & Keamanaan & Kesehatan \\
\hline
\end{tabular}

Sumber: Kompas, 2019 
Instrumen utama dalam penelitian ini adalah peneliti sendiri. Menurut (Barnawi \& Darojat, 2018; Cresswell, 2017); Rahardjo (2017) peneliti sendiri merupakan instrumen kunci, sehingga peneliti sendiri yang dapat mengukur ketepatan dan ketercukupan data serta kapan pengumpulan data harus berakhir. Namun tetap digunakan instrumen seperti lembar wawancara, alat perekam, dan kamera untuk membantu peneliti dalam mengambil data di lapangan. Data di lapangan dikumpulkan dengan pencatatan dokumen, observasi, dan wawancara mendalam berdasarkan proposisi dari indikator yang digunakan oleh IKCI 2018. Proposisi yang digunakan dalam penelitian ini terdapat pada Tabel 1.

Data yang telah terkumpul kemudian dianalisis secara kualitatif. Keseluruhan data yang terkumpul kemudian dipilah dan disusun berdasarkan deret waktu (time line) terjadinya peristiwa. Deret waktu digunakan untuk melihat deretan waktu setiap peristiwa yang dianggap berkontribusi dalam pencapaian peringkat pertama smart city, sehingga dapat diketahui proses yang dilakukan pemerintah Kota Denpasar dalam mencapai peringkat pertama smart city.

Data yang didapatkan kemudian dianalis dengan menggunakan teknik proses hubungan dan deret waktu secara deskriptif. Hasil analisis tersebut kemudian di crosscheck dengan fase proses lainnya. Kemudian setiap data dilakukan triangulasi dengan sumber bukti lainnya.

Kemudian dari deret waktu tersebut akan dianalisis untuk melihat hubungan, keterkaitan, dan bagaimana hubungannya. Hasi analisis tersebut akan memunculkan faktor-faktor yang menyebabkan terjadi pencapaian peringkat pertama smart city dengan berbekal kisi-kisi dari proposisi teoritis sebelumnya. Yin (1996) menyampaikan terdapat dua strategi umum dalam alisis studi kasus, yakni mendasarkan pada proposisi teoritis dan dengan pendekatan deskriptif terhadap kasus. Penelitian ini mendasarkan pada proposisi teoritis dikarenakan sudah terdapat proposisi teoritis sebelumnya, namun proposisi teoritis tersebut hanya sebagai kisi-kisi di lapangan, tidak untuk diuji.

Setelah keseluruhan data dianalisis kemudian dilakukan pembahasan banding terhadap Kota Surabaya yang memiliki kasus serupa. Pembahasan mengenai tahapan Kota Surabaya didasarkan pada penelitian yang dilakukan oleh penulis lainnya. Hal tersebut dikarenakan tidak memungkinnya penulis untuk melakukan penelitian di Kota Surabaya. Terakhir dilakukan pembahasan terhadap kasus di Kota Denpasar.

\section{HASIL DAN PEMBAHASAN}

\section{Proses dan Faktor-Faktor Yang Mempengaruhi Kota Denpasar Menuju Smart City}

Kota Denpasar pada awalnya tidak berfokus pada pengembangan smart city, namun hanya berupaya untuk memberikan pelayanan yang mudah dan efisien kepada masyarakat. Sekitaran tahun 2016 berkembanglah istilah smart city di Indonesia. Perkembangan tersebut kemudian membuat Kota Denpasar berinisiatif mengembangkan Denpasar Smart City. Kota Denpasar mulai mengembangkan smart city pada tahun 2017 dengan didirikannya ruangan Damamaya Denpasar Cyber Monitor (DCM). Walaupun Kota Denpasar mulai mengaku mengembangkan smart city pada tahun 2017, namun sebenarnya telah terdapat program yang mengarah pada smart city yang dilakukan sebelumnya. 
Berdasarkan hasil penelitian terdapat tiga tahapan yang dilakukan Kota Denpasar menuju Denpasar Smart City, yakni tahapan pemanfaatan TIK, tahapan pembangunan masyarakat dan hadirnya PRO Denpasar, serta tahapan inovasi berorientasi smart city. Lebih jelasnya tergambarkan pada Gambar 1.

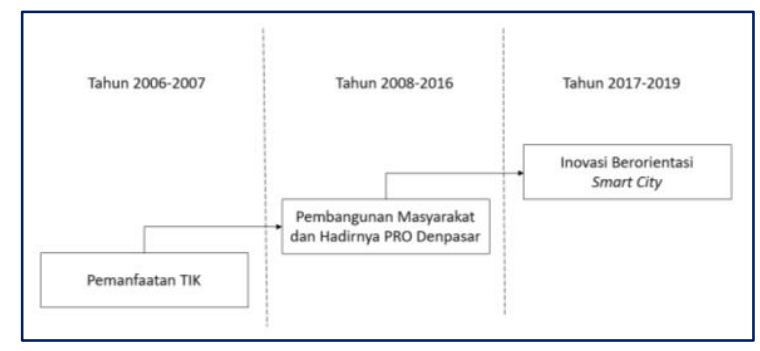

Gambar 1. Tahapan Kota Denpasar Menuju Smart City

Sumber: Analisis, 2019

Kota Denpasar pada awalnya membangun jaringan topologi bintang untuk mengembangkan cyber school. Studi banding dilakukan terlebih dahulu ke Rumah Pintar Yogyakarta dan kemudian membangun jaringan topologi bintang bersama mahasiswa yang magang atau PKL di Dinas Pendidikan dan Kepemudaan Kota Denpasar.

Kemudian tahun 2007 Kota Denpasar membangun call center safe community dengan nomor panggilan 223333. Pada tahun 2014 kepala UPT Pusdalop yang baru membuat akun facebook pusdalop Denpasar, yang kemudian menyebabkan terjadinya peningkatan partisipasi masyarakat dalam pemanfaatan call center tersebut.

Setelah melakukan pembangunan jaringan berbasis TIK, Pemerintah Kota Denpasar kemudian melakukan pembangunan masyarakat. Hal yang menarik dari pembangunan masyarakat yang terjadi di Kota Denpasar bersifat topdown dan bottom-up. Pembangunan yang bersifat top-down yakni pembangunan yang dilakukan oleh Pemerintah Kota Denpasar. Sedangkan pembangunan yang bersifat bottom-up yakni pembangunan yang diinisasi dari masyarakat langsung.

Pembangunan yang bersifat top-down diantaranya Pusat Pelayanan Autis (PLA) Kota Denpasar, yang didirikan atas inisiatif Ketua PKK Kota Denpasar. Kemudian Rumah Pintar Denpasar, yang didirikan atas instruksi dari Ibu Negara. Kemudian revitalisasi pasar tradisional, pendirian Denpasar Design Center (DDC), bus sekolah gratis, dan denpasar mantap pelayanan kesehatan (Damakesmas).

Pembangunan yang bersifat top-down tersebut tidak terlepas dari faktor kepemimpinan, kerja sama, inspirasi eksternal, dan inovasi serta komitmen Pemerintah Kota Denpasar.

Kemudian pembangunan yang bersifat bottom-up diantaranya, Komunitas Tukad Bindu yang telah melakukan revitalisasi di bantaran Sungai Tukad Bindu menjadi ruang publik yang indah dan nyaman, dan komunitas Badan Kreatif Pemuda (BEDA) Denpasar yang menginisiasi adanya Youth Park Denpasar.

Pembangunan Komunitas Tukad Bindu dan BEDA Denpasar memiliki proses yang cukup berbeda. Komunitas Tukad Bindu berdiri karena adanya seorang tokoh bernama A.A. Rai Temaja yang merupakan Kepala Lingkungan Banjar Ujung (tempat beradanya revitalisasi tukad bindu) yang menginisiasi berdirinya komunitas tersebut. Sedangkan BEDA Denpasar awalnya diinisasi oleh I Putu Hendika Pernama bersama rekan-rekannya yang mengusulkan untuk dibuatkan taman pemuda kepada Wali Kota Denpasar, dan saat ini terbentuklah Yout Park di Taman Kota Denpasar. 


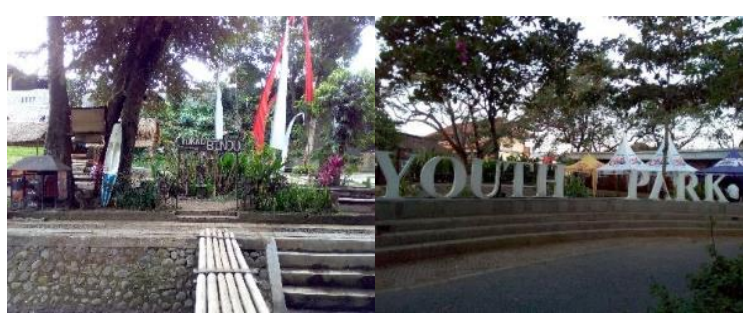

Gambar 1. Tukad Bindu (kiri) dan Youth Park (kanan)

Sumber: Dokumentasi Pribadi, 2018.

Partisipasi masyarakat yang dilakukan oleh Komunitas Tukad Bindu merupakan bentuk partisipasi nyata yang dilakukan secara mandiri. Hal ini nampaknya sesuai dengan pernyataan yang dikemukakan oleh Firdaus (2018) bahwa pada tahapan terakhir dari partisipasi masyarakat adalah partisipasi dengan karakter mandiri. Sedangkan Komunitas BEDA Denpasar merupakan bentuk dari adanya good governance di Kota Denpasar, karena adanya respon yang baik dari Wali Kota Denpasar terhadap kalangan pemuda. Nampaknya apa yang disebut sebagai sustainable urban democracy telah terimplementasi dengan baik (Yunus, 2015).

Pada tahun 2013 Pemerintah Kota Denpasar mengeluarkan Peraturan Wali Kota Nomor 45 Tahun 2013 Tentang Penanganan Pengaduan. Perwali tersebut kemudian menjadi dasar dari dibuatnya aplikasi pengaduan rakyat online (PRO) Denpasar. Aplikasi ini dapat dikatakan awal dari mulai terlihatnya Smart City Denpasar. Karena fokus dari Smart City Denpasar adalah penangan pengaduan masyarakat.

[...] nah mangkin (sekarang) per 2013 kita konsepkan, pertama melalui sistem. Sistemnya yang kita bangun dumun (duluan), artinya secara mobile, secara Web. [...] itu yang kita konsep 2013" (Bapak Dewa Rama, koordinator Damamaya DCM)
Perkembangan selanjutnya dari PRO Denpasar tidak hanya melayani pengaduan saja, namun telah terdapat berbagai informasi dan data-data yang dibutuhkan oleh masyarakat. Aplikasi PRO Denpasar pun berubah nama menjadi PRO Denpasar+ dengan tambahan berbagai fitur. PRO Denpasar+ memiliki konsep "Demi Denpasar-Denpasar Satu”, yakni menyatukan seluruh aplikasi mobile yang dimiliki oleh Pemerintah Kota Denpasar, sehingga dapat diakses dalam satu genggaman.

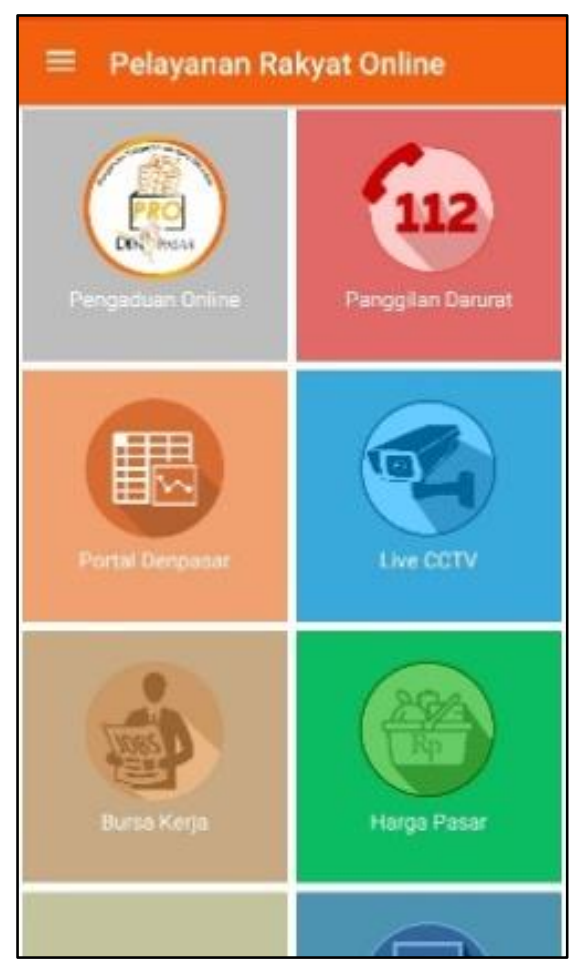

Gambar 2. Tampilan PRO Denpasar+ Sumber: Dokumentasi Pribadi, 2018.

Keseriusan Kota Denpasar dalam mengembangkan smart city dengan berfokus pada pengaduan masyarakat terlihat dari dibangunanya Damamaya Denpasar Cyber Monitor (DCM). Damamaya DCM yang diresmikan pada tahun 2017 tersebut memiliki fungsi untuk melakukan berbagai aktifitas terkait dengan PRO Denpasar+. Damamaya DCM terdiri dari tiga ruangan, yakni monitor room, 
command room, dan squad news production. Damamaya DCM dapat dikatakan sebagai salah satu bentuk keseriusan Kota Denpasar dalam mengembangkan smart city.

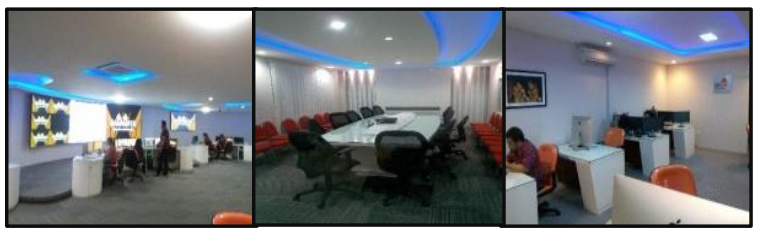

Gambar 3. Monitor Room (kiri), Command Room (tengah), DCM Squad News

Production (kanan).

Sumber: Dokumentasi Pribadi, 2018.

Secara umum program-program yang dilakukan Kota Denpasar menuju smart city terdapat pada Tabel 2. Berdasarkan Tabel 2, terlihat bahwa tidak semua indikator dari IKCI 2018 diakomodir oleh programprogram yang dimiliki oleh Kota Denpasar. Namun, tidak semua dimensi dari IKCI 2018 terpenuhi. Hal ini mengartikan bahwa program-program yang dimiliki oleh Kota Denpasar sudah mengakomodir beberapa indikator. Bila dibandingkan dengan indikator IKCI 2018, dimensi masyarakat yang dipenuhi terlebih dahulu oleh Kota Denpasar. Kemudian berlanjut pada pemenuhan dimensi kualitas hidup, ekonomi, pemerintahan, lalu dimensi mobilitas.

Menurut Giffinger (2007) terdapat enam dimensi smart city, yakni smart economy, smart mobility, smart environment, smart people, smart living, dan smart governace. Pada umum kota-kota di seluruh dunia memang hanya mengembangkan enam dimensi saja, namun Kota Denpasar mengembangkan dua dimensi lagi, yakni smart philosophy dan smart creativity. Pengembangan dua dimensi baru yang dilakukan Kota Denpasar merupakan cerminan bahwa smart city tidak bersifat kaku, artinya dapat dimodifikasi dan dikembangkan sendiri sesuai dengan kebutuhan dan karakter kota.
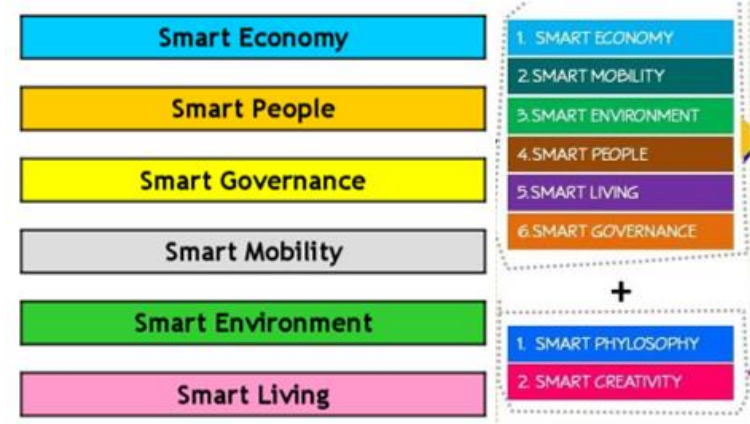

Gambar 3. Dimensi smart city pada umumnya (kiri) dan dimensi Denpasar Smart City (kanan)

Sumber: Giffinger, 2007 (kiri) dan Road Map Denpasar Smart City, 2016 (kanan)

\section{Pembahasan Banding Dengan Kota Surabaya Dalam Konteks Smart City}

Kota Surbaya merupakan peraih peringkat pertama smart city IKCI 2018 pada kategori kota metropolitan. Berdasarkan penelitian yang dilakukan oleh Widyaningsih (2013) terdapat empat fase yang dilakukan Kota Surabaya menuju smart city. Fase tersebut yakni, fase I pembenahan internal pemerintahan, fase II penguatan modal sosial, fase III pengembangan layanan eksternal pemerintahan, fase IV pengembangan layanan kota berbasis teknologi tinggi.

Kota Surabaya mulai fokus untuk mengembangkan smart city pada tahun 2011 setelah mendapatkan penghargaan Smart City Award 2011, walaupun berdasarkan hasil penelitian Widyaningsih (2013) menujukan sebenarnya Kota Surabaya mulai terlihat mengembangkan smart city sejak tahun 2003. Sedangkan Kota Denpasar mulai fokus mengembangkan smart city pada tahun 2017 dikarenakan adanya moment smart city sekitaran tahun 2017 dan dengan didirikannya Damamaya DCM. Walaupun 
sebenarnya Kota Denpasar telah berfokus pada satu dimensi saja. Sedangkan memulainya sejak tahun 2006.

Kota Denpasar lebih berfokus pelayanan

Kota Denpasar dan Kota Surabaya samapengaduan masyarakat, melalui PRO sama mengembangkan infrastruktur Denpasar. Kota Denpasar juga meraih berbasis TIK dan pembangunan predikat kota layak huni dengan indeks masyarakat. Pemimpin yang sama-sama yang terus meningkat. Berdasarkan berkomitmen dalam mengembangkan smart penelitian yang dilakukan oleh Graha city, nampaknya menjadi faktor yang utama (2019), menunjukan bahwa aplikasi PRO untuk memulai smart city. Denpasar dapat menjembati masyarakat Kota Surabaya menggunakan dengan pemerintah dalam pemenuhan pendekatan yang holistik dalam kebutuhan kota layak huni. mengembangkan smart city, sehingga tidak 
Tabel 2.

Program-program Menuju Denpasar Smart City

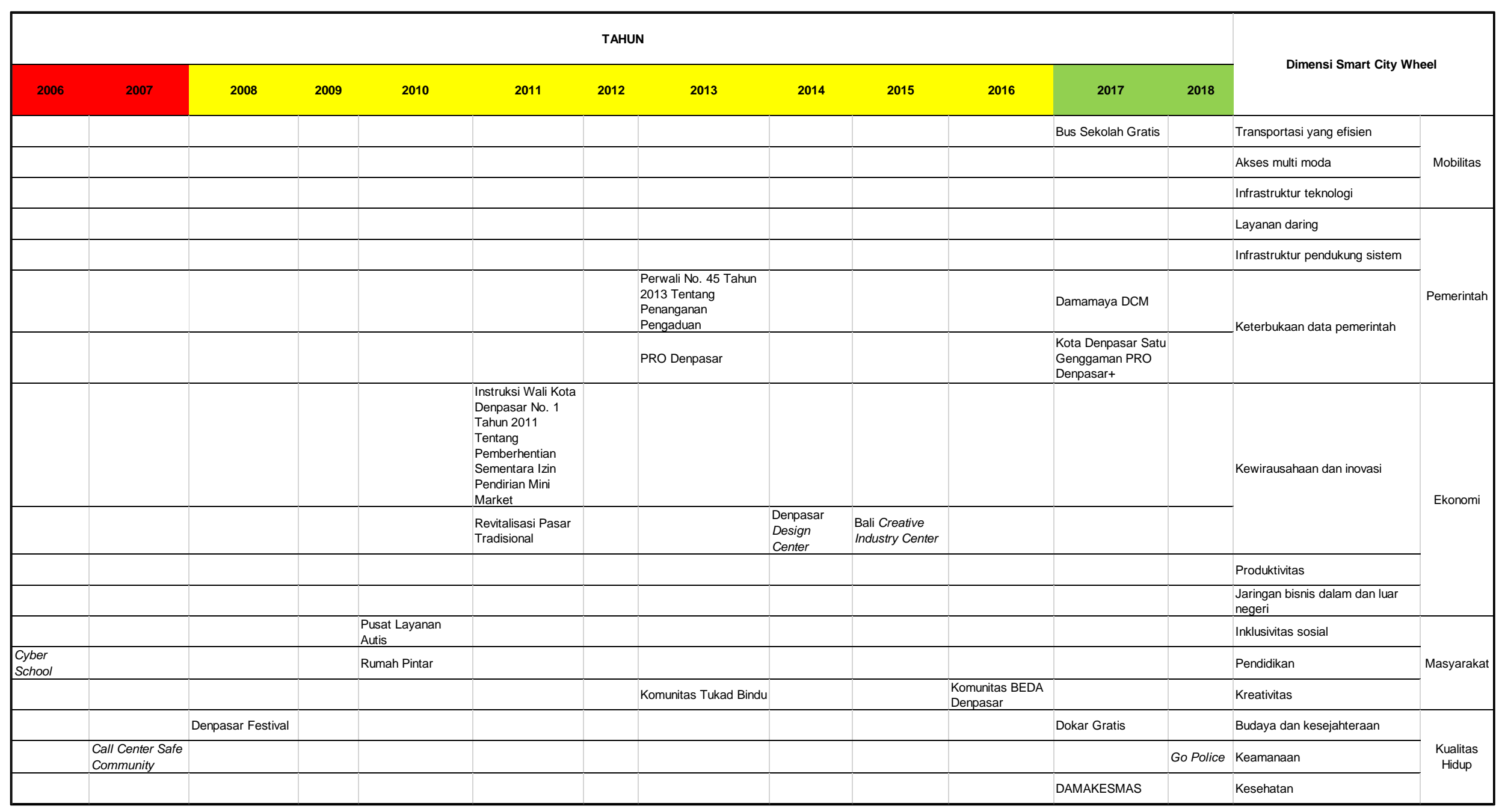

Sumber: Analisis Penulis, 2019 


\section{Pembahasan Teoritik}

Denpasar Smart City terlihat hanya berlangsung secara teknis, seperti adanya PRO Denpasar, Damamaya DCM, dan yang lainnya. Pada hal sebenarnya ada proses secara politis yang berlangsung. Tidak mungkin suatu program dapat berjalan lancar tanpa adanya proses politis yang berlangsung, mengingat setiap pembangunan kota terdapat berbagai kepentingan. Tidak jarang ada benturan antar kepentingan-kepentingan tersebut. Chapin dalam (Sutriadi, 2018) mengungkapkan bahwa terdapat proses perencanaan secara teknis dan secara politis dalam mewujudkan smart city.

Berhasilnya pembangunan kota merupakan cerminan atas terakomodirnya berbagai kebutuhan penghuni kota. Kepentingan tersebut yakni kepentingan politik, bisnis (kapitalis), dan pemenuhan kebutuhan masyarakat. Pemerintah, pengusaha, dan masyarakat harus memiliki kekuatan yang sama dan berimbang dalam membangun kota. Ketika salah satu lebih mendominasi, maka apa yang pernah diungkapkan oleh Peter Ambrose dapat menjadi kenyataan. Jika pemerintah lebih mendominasi maka akan menjadi konservatif, jika pebisnis lebih mendominsi maka akan menjadi kapitalis, jika masyarakat lebih mendominasi maka akan menjadi radikal (Ambrose, 2003)

Kota Denpasar memilih Dinas Komunikasi Informasi dan Statistik sebagai leader pelaksana Denpasar Smart City. Kota-kota yang menerapkan smart city di Indonesia pada umumnya memang memilih Diskominfo atau Bappeda sebagai leader pelaksana smart city. Tetapi sebaiknya memilih Bappeda sebagai leader pelaksananya, karena smart city bersifat menyeluruh pada berbagai aspek. Walau demikian, Kota Denpasar melaksanakan berbagai dimensi smart city-nya secara menyeluruh pada berbagai dinas-dinas atau OPD-nya masing-masing.

Masalah yang sering dihadapi kota-kota di Indonesia dalam pelaksanaan smart citynya adalah dana penganggaran. Smart city baru popular dan dikembangkan pada beberapa dekade ini, sedangkan dokumen perencanaan jangka menengah (RPJM) dan dokumen perencanaan jangka panjang (RPJMP) sudah terlanjur ditetapkan. Mungkin kita dapat belajar dari Kota Denpasar. Program-program yang menunjang smart city dibuat dengan mengacu pada RPJM dan RJMP yang sudah ditetapkan sebelumnya. Sehingga dapat dikatakan program-program smart city tersebut terimplementasi dengan ikut bergandeng dengan RPJM dan RPJMP yang telah ada.

Pengembangan dimensi baru yang dikembangkan oleh Kota Denpasar, yakni smart philosophy dan smart creativity, merupakan hal yang baru. Smart philosophy merupakan dimensi yang 
memayungi dimensi-dimensi Denpasar Smart City lainnya.

"Smart Philosphy ini yang memayungi secara keseluruhan dari enam dimensi tersebut termasuk juga Smart Creativity" (Anindya Putra, ketua pusat studi pembangunan perkotaan dan wilayah universitas hindu Indonesia)

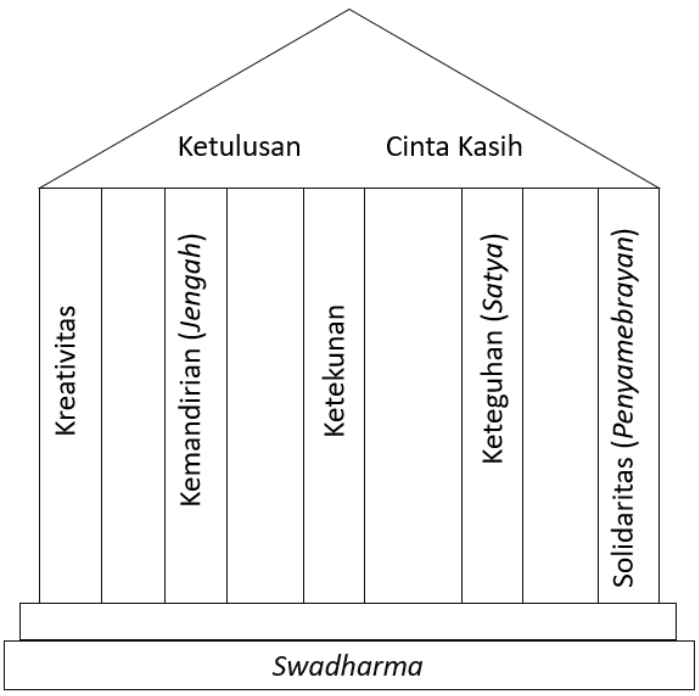

Gambar 4. Visualisasi Monumen Maya Kota Denpasar.

Sumber: Digambar ulang dari Mantra (2014)

Smart Philosphy merupakan sikap cerdas dan bijak Pemerintah Kota Denpasar dalam meletakan dasar segala gerak langkah pembangunan Kota Denpasar berwawasan Budaya Bali yang dijiwai secara konkret dengan pengejewantahan Konsep Tri Hita Karana, Sewaka Dharma, Rwa Bhineda,
Tattwan Asi, Asah Asih Asuh, dan yang lainnya. Konsep-Konsep tersebut tertuang dalam Monumen Maya Kota Denpasar.

Monumen Maya Kota Denpasar merupakan penanda kesadaran yang membuat manusia selalu bergerak meraih kualitas hidup yang lebih baik (Mantra, 2014). Monumen Maya Kota Denpasar di dasari oleh Swadharma, kemudian di tunjang oleh lima pilar yakni kreativitas, kemandirian (jengah), ketekunan, keteguhan (satya), dan solidaritas (penyamabrayan), kemudian dipayungi oleh ketulusan dan cinta kasih. Gambaran mengenai Monumen Maya Kota Denpasar terdapat pada Gambar 4.

Swadarma merupakan passion yang menuntun orang untuk memilih peran dan mengimaninya. Passion itu akan menjadi mesin utama dari gerak kehidupan dan ketika setiap orang menyadari Swadharmanya kehidupan akan bergerak harmonis. Kreativitas akan mendorong seseorang untuk selalu menjadikan kehidupan hari ini akan lebih baik dari sebelumnya, beranjak dari kebaikan yang satu ke kebaikan yang lebih tinggi. Saat kreativitas tersebut diimani akan melahiran Taksu (inner power) yang memberikan keindahan dan mujizat. Kemandirian (jengah) menjadikan gerak manusia-manusia kreatif tidak bergantung dan memberati manusia lainnya. Kemandirian tersebut akan menjadi dasar perlawanan terhadap segala bentuk pemanfaatan. 
Ketekunan menjadi penyangga utama dalam mewujudkan gagasan kreatif. Ketekunan akan memungkinkan hal-hal yang semula kecil menjadi inspirasi yang lebih besar. Keteguhan hati (satya) membuat setiap orang berani dan sanggup menghadapi setiap kendala untuk mejalankan Swadharma. Solidaritas (penyamabrayan) merupakan kebersamaan dan kerjasama baik individu dengan individu, individu dengan kelompok, ataupun kelompok dengan kelompok. Ketulusan dan Cinta Kasih yang memayungi Monumen Maya Kota Denpasar merupakan hal menjiwai gerak manusia untuk memuliakan manusia lain, makhluk lain, dan alam sekitarnya, serta selalu menautkan diri untuk mendapat bimbingan dari Tuhan.

Smart Philosphy merupakan kearifan lokal yang dimiliki Kota Denpasar yang memiliki peran dalam meningkatkan indeks kota layak huni. Hal ini sesuai dengan yang diungkapkan oleh Gandarum (2016) bahwa pengetahuan lokal (kearifan lokal) memainkan peranan penting dalam menciptakan ruang kota layak huni yang berpusat pada manusianya. Karena menjadikan kota menjadi layak huni merupakan salah satu wujud pembangunan berkelanjutan yang juga merupakan tujuan dari smart city.

Banyak kota-kota di dunia bahkan di Indonesia masih menganggap bahwa smart city berarti kota yang berteknologi canggih dengan perlengkapan TIK. Teknologi yang canggih sebenarnya bukan priyoritas, tetapi bagaimana mensejahterakan penghuni kota secara berkelanjutan. Itu yang menjadi tujuan smart city yang sesungguhnya. Membangun kota secara bersama merupakan kunci mewujudkan itu semua.

\section{SIMPULAN}

Kota Denpasar mengalami tiga tahapan dalam mengembangkan smart city, yakni tahap I pengembangan TIK, tahap II pembangunan masyarakat dan hadirnya PRO Denpasar, tahap III inovasi berorientasi smart city. Berlangsungnya setiap tahapan tersebut disebabkan oleh faktor kepemimpinan, kerja sama dengan pihak lain, inspirasi eksternal, dan inovasi serta komitmen Pemerintah Kota Denpasar.

Kota Surabaya melalui empat fase dalam mengembangkan smart city, yakni fase I pembenahan internal pemerintahan, fase II penguatan modal sosial, fase III pengembangan layanan eksternal pemerintahan, fase IV pengembangan layanan kota berbasis teknologi tinggi. Sedangkan Kota Denpasar melalui tiga tahapan. Kota Surbaya menggunakan pendekatan yang holistik dalam pengembangan smart city, sehingga tidak berfokus pada satu dimensi. Sedangkan, Kota Denpasar lebih berfokus pada penangan pengaduan masyarakat, melalui PRO Denpasar. Kota Surabaya mengembangkan enam dimensi, seperti kota-kota lain pada umumnya. Sedangkan 
Kota Denpasar mengembangkan dua takutnya justru akan menjadi "boomerang" dimensi baru, yakni smart philosophy dan smart creativity.

Smart city menjadi tren pengembangan kota di seluruh dunia, termasuk di Indonesia. Nampak terlihat pula banyak kota-kota di Indonesia yang tidak sabar dan terasa tergesa-gesa dalam mengembangkan smart city. Smart city terlihat seperti sebuah gengsi, yang terkesan jika kota tidak "smart" maka tidak modern. Hal ini bisa menjadi sebuah hal baik dalam pengembangan kota kedepannya, namun jika hanya mencari "gengsi" semata, bagi kota tersebut.

Setiap kota di Indonesia yang ingin mengembangkan smart city, sebaiknya memperkuat pembangunan masyarakat terlebih dahulu. Mengingat apa yang dilakukan oleh Kota Denpasar dan Kota Surabaya lebih pada pembangunan masyarakat. Smart city harus didukung masyarakat yang cerdas, kota yang cerdas adalah kota yang berhasil mencerdaskan masyarakatnya. Setiap kota bebas dalam mengembangkan dimensi smart city, sesuai dengan kebutuhan dan "jiwa” kotanya.

\section{DAFTAR PUSTAKA}

Ambrose, P. (2003). Urban Process And Power New york: Routledge

Barnawi, \& Darojat, J. (2018). Penelitian Fenomenologi Pendidikan Teori Dan Praktik. Yogyakarta: Ar-Ruzz Media.

Cresswell, J. W. (2017). Research Design Pendekatan Kualitatif, Kuantitatif, dan Mixed (A. Fawaid, Trans.). Yogyakarta: Pustaka Pelajar.

Firdaus. (2018). Pekanbaru Madani Dari Metropolitan Menjadi Smart City Menuju Masyarakat Madani. Jakarta: Elex Media Komputindo.

Gandarum, D. N. (2016). Inquiry Paradigm For Understanding Livable Urban Space In Local Knowledge Framework. Prosiding Seminar Kota Layak Huni / Livable Space(2016: Applying Local Knowledge for Livable Space).

Giffinger, R. (2007). Smart cities Ranking of European medium-sized cities [Press release]. Retrieved from http://www.smartcities.eu/download/smart_cities_final_report.pdf

Graha, I. M. S. (2019). Faktor-Faktor Yang Mempengaruhi Peningkatan Indeks Kota Layak Huni Di Kota Denpasar Tahun 2006-2017. (Master), Universitas Gadjah Mada, Yogyakarta (Tesis Tidak Diterbitkan).

Kompas. Kota Cerdas Hadirkan Solusi Masalah Warga. Senin, 14 Januari 2019. Hal. 1 
Mantra, I. B. R. D. (2014). Membangun Monumen Maya Menggerakan Partisipasi Menuju Denpasar Sejahtera. Paper presented at the Seminar Nasional HUT Kota Denpasar Ke-226 Representasi Sinergi Budaya, Kreativitas, dan Pendidikan Menuju Kesejahteraan Berkelanjutan, Kota Denpasar.

Rahardjo, M. (2017). Studi Kasus Dalam Penelitian Kualitatif: Konsep Dan Prosedurnya Malang: Program Pascasarjana Universitas Islam Negeri Maulana Malik Ibrahim

Sutriadi, R. (2018). 10 Langkah Mencerdaskan Kota. Bandung: Penerbit ITB.

Widowati, I. R. (2017). Smart Infrastruktur (Infrastruktur Cerdas) Untuk Mewujudkan Perkotaan Layak Huni dan Berkelanjutan. Prosiding Seminar Nasional Inovasi Dalam Pengembangan SmartCity, 1(1).

Widyaningsih, D. (2013). Kota Surabaya Menuju Smart City. (Master), Universitas Gadjah Mada, Tesis Tidak Diterbitkan.

Yin, R. K. (1996). Studi Kasus Desain Dan Metode (M. D. Mudzakir, Trans.). Jakarta: Raja Grafindo Prasada.

Yunus, H. S. (2015). Manajemen Kota Perspektif Spasial. Yogyakarta: Pustaka Pelajar. 